\title{
RENT TAXATION AND ITS INTERTEMPORAL WELFARE EFFECTS IN A SMALL OPEN ECONOMY
}

\author{
MARKO KÖTHENBÜRGER \\ PANU POUTVAARA
}

CESIFO WORKING PAPER NO. 2158

CATEGORY 1: Public FinANCE

DECEMBER 2007

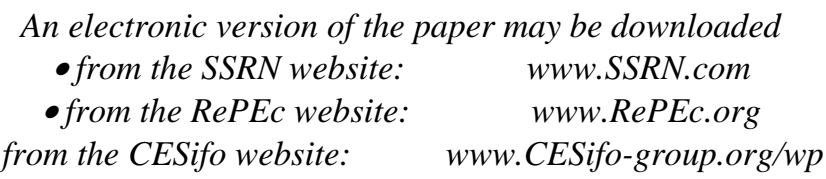




\title{
RENT TAXATION AND ITS INTERTEMPORAL WELFARE EFFECTS IN A SMALL OPEN ECONOMY
}

\begin{abstract}
Previous literature concludes that replacing wage taxation by taxes on a fixed factor or its rents benefits future generations. However, the effects of such steady-state gains on the transition generations have been left open. In this paper, we show that taxation of rents may also increase utility of the current generation provided tax revenues are earmarked to reduce wage taxes. In particular, a shift in the tax mix may yield an intergenerational Paretoimprovement when the initially prevailing tax mix is sufficiently skewed towards wage taxation.
\end{abstract}

JEL Code: H22, E62, F02.

Keywords: rent taxes, capitalization, transitional dynamics, labor supply, asset prices.

Marko Köthenbürger

Center for Economic Studies (CES)

at the University of Munich

Schackstr. 4

80539 Munich

Germany

marko.koethenbuerger@ces.vwl.uni-

muenchen.de
Panu Poutvaara

University of Helsinki

Department of Economics

P.O. Box 17

Arkadiankatu 7

00014 Helsinki

Finland

panu.poutvaara@helsinki.fi 


\section{Introduction}

Rent taxation influences resource allocation through various channels. Feldstein (1977) shows that a rent tax promotes capital accumulation. The rent tax lowers the price of the fixed factor (e.g. land), which reallocates a higher fraction of savings in the households' portfolio choice to the accumulation of physical capital. Consequently, welfare of steady state generations rises. ${ }^{1}$ The effect is, of course, non-existent in a small open economy in which the household portfolio choice and domestic capital accumulation are disconnected (e.g. Eaton, 1988). As shown by Petrucci (2006), rent taxation may still be beneficial in a small open economy provided households endogenously supply labor. For instance, when rent tax revenues are spent on the reduction of distortionary wage taxes, labor supply increases; an effect which is welcomed by steady state generations. They enjoy a lower wage tax without incurring a drop in the price of their land holdings. The latter cost of rent taxation is borne by transitional generations. The intriguing question is whether the transition generation are able to benefit from rent taxation. Petrucci (2006) analyzes the effect on steady-state generations, leaving the effect on transition generations, alive at the time of the reform, open.

One instrument to accomplish an intergenerational Pareto-improvement might be an intergenerational transfer, such as social security payments or public debt. Instead, this paper analyzes whether the positive welfare effects of rent taxation extend to transition generations in the absence of these public transfer institutions. We show that market-based adjustments may, in fact, realize an intergenerational welfare improvement. Concretely, provided the initially prevailing level of wage taxes is sufficiently high, introducing rent taxes to reduce wage taxes increases the sum of rental income and land value of the transitional

\footnotetext{
${ }^{1}$ Among others, Calvo et al. (1979), Chamley and Wright (1987) and Ihori (1990) analyze refinements of the effect.
} 
generation. The rationale is that the rise in labor supply raises the marginal productivity of land which capitalizes in the market price of land. As such, earmarking rent tax revenues is helpful in realizing an intergenerational Pareto-improvement. Rent taxation induces a forward intergenerational transfer from transitional generations to steady state generations. The earmarking simultaneously yields a backward, market-based reaction in asset values, which compensates, possibly to a full extent, transitional generations. ${ }^{2}$

The importance of the capitalization mechanism for intergenerational policy is also analyzed in Rangel (2005). Rangel assumes an economy that lasts for two periods and has two overlapping generations. The older generation owns land and sells it to the younger generation in the second period. There are intergenerational public expenditures (e.g. public infrastructure) that benefit the younger generation in the second period. This investment is more efficient to do in the first period. Taxation is restricted to either income taxation or land taxation, and taxes are paid in the first period by the older generation and in the second period by the younger generation. The older generation can also use public debt; thereby expropriating the younger generation. Rangel shows that income taxes yield a less tight link between the fiscal treatment of future generations and the current land price. The reason is that changes in income taxes affect land price only to the extent that demand for land changes through income effects, while land taxes, which are levied in the second period to top up the investment of the old generation or to repay debt accumulated in the first period, capitalize directly into land prices. Rangel concludes that restricting tax instruments to land taxes, rather than allowing for income taxes, would improve efficiency in the provision of intergenerational goods.

Our analysis differs from Rangel (2005) in three ways. First, Rangel assumes that the

\footnotetext{
${ }^{2}$ Rangel (2003) analyzes how the provision of forward and backward intergenerational goods (e.g. old-age social security and education) intertwine so as to ensure the political viability of intergenerational transfers. Here, we establish a backward link across generations by means of the market mechanism. Rangel (2003) analyzes an economy in which incomes are exogenous and there is no land or any other fixed factor.
} 
income tax base is exogenously given, i.e. there is no endogenous labor supply, and that the level of public expenditures is endogenous. We assume, instead, that labor supply is endogenous, and public expenditures are exogenous. Thus, Rangel analyzes the allocation of given resources between private consumption and public expenditures, while we analyze the efficient financing of given public expenditures when total production is endogenous and labor supply responds to the way taxes are collected. Second, we assume that the government has no access to lump-sum taxes but can only tax wages and rental income, while Rangel allows government to levy either lump-sum taxes or land taxes. Third, Rangel focuses on the interest conflict between different generations, recommending constitutional restrictions to taxing only land to protect future generations. We find, instead, that there is scope for an intergenerational consensus: current and future generations have to a certain extent a joint interest in relying on land taxes rather than income taxes.

The presence of intergenerational trade need not always improve efficiency. Poutvaara (2003) shows that the presence of intergenerational trade in a fixed factor of production that is complementary to human capital may result in overprovision of public education from the efficiency point of view. In Poutvaara (2003), the current and future working-age generations have an option to decide whether to pay taxes to provide education publicly to the younger generation, or leave investment in education to be decided privately. There are no taxes on land rents.

Finally, this paper is also related to Koethenbuerger and Poutvaara (2006). Therein, the focus is on the size of the pay-as-you-go social security system. A reduction in the social security contribution rate increases future human capital stock, which is capitalized in the current land prices. Under certain conditions, the capital gain for pensioners, resulting from increased human capital formation, may exceed the cut in pensions, allowing for a Paretoimproving social security reform. The government is restricted to tax wages. This paper, 
instead, allows the government to tax also land rents, in line with Rangel (2005).

The structure of the paper is as follows: In section 2 we introduce the model. In section 3 we analyze the welfare implications of a reform of the tax mix. We provide a concluding discussion in section 4.

\section{The Model}

Consider a small open economy whose population size is normalized at unity. In any period $t$ production combines three input factors: capital, labor and land. The amount of land is normalized to unity. Labor and capital in the economy in period $t$ are denoted by $L_{t}$ and $K_{t}$, respectively. The production function $Y_{t}=F\left(L_{t}, K_{t}\right)$ exhibits constant returns to scale in all three factors. Capital is internationally mobile. All markets are competitive, and therefore profit maximization implies

$$
w_{t}=F_{L_{t}}\left(L_{t}, K_{t}\right), \quad r=F_{K_{t}}\left(L_{t}, K_{t}\right) .
$$

$w_{t}$ denotes the wage rate in period $t$ and $r$ is the interest rate determined in the international capital market. The land rent in period $t, R_{t}$, is given as residual

$$
R_{t}=F\left(L_{t}, K_{t}\right)-F_{L_{t}}\left(L_{t}, K_{t}\right) L_{t}-F_{K_{t}}\left(L_{t}, K_{t}\right) K_{t}
$$

Individuals can invest their savings in the international capital market or the national land market. We assume that foreigners do not invest in the national land market. Even with integrated capital markets, full domestic land ownership could be guaranteed by foreigners facing a small transaction cost if they were to buy domestic land. In line with Gordon 


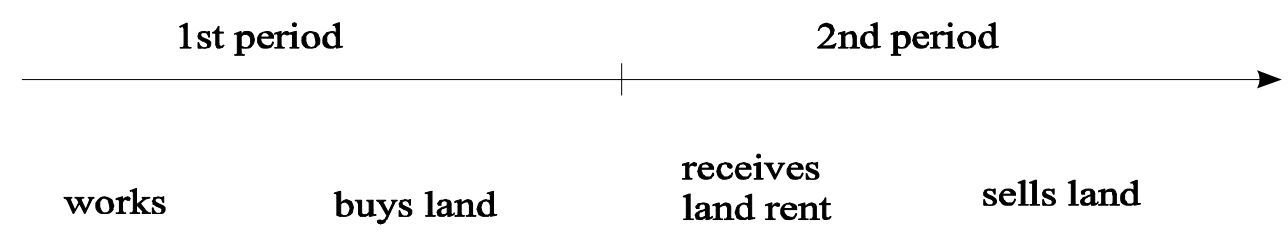

Figure 1: Sequence of decisions.

and Bovenberg (1996), a transaction cost in foreign land acquisition might arise due to asymmetric information on the part of investors. Such asymmetries tend to play a diminished role in international loan markets. The economy produces a composite good, which is a perfect substitute for that produced abroad. Rents are taxed at a rate $\tau^{R}<1$. By arbitrage, land value in period $t, V_{t}$, is given $\mathrm{by}^{3}$

$$
(1+r) V_{t}=\left(1-\tau^{R}\right) R_{t+1}+V_{t+1}
$$

We analyze an overlapping generations model in which each cohort lives for two periods. Since each cohort consists of homogenous households, we consider a representative household for each cohort. The sequence of decisions is depicted in Figure 1. In the first period of their life individuals born in period $t$ choose their labor supply $l_{t}$ and savings invested in financial assets $s_{t}$ and land acquisition $V_{t}$ from the old generation. In the second period of life, individuals receive the rent payment $R_{t+1}$, sell land to the current young generation and use the receipts along with the deaccumulation of financial assets $s_{t}(1+r)$ to finance secondperiod consumption $c_{t+1}^{2}$. In addition to the rent $\operatorname{tax} \tau^{R}$, the government imposes a tax $\tau^{w}$

\footnotetext{
${ }^{3}$ We save on notation by omitting time subscripts for the rent and wage tax rate.
} 
on wage income. The first and second period budget constraints thus are

$$
\begin{aligned}
\left(1-\tau^{w}\right) l_{t} w_{t}-c_{t}^{1}-s_{t}-V_{t} & =0 \\
s_{t}(1+r)+\left(1-\tau^{R}\right) R_{t+1}+V_{t+1}-c_{t+1}^{2} & =0 .
\end{aligned}
$$

Household utility is

$$
U\left(1-l_{t}, c_{t}^{1}, c_{t+1}^{2}\right)=c_{t}^{1}+\rho \ln c_{t+1}^{2}-\frac{\gamma}{1+\gamma} l_{t}^{\frac{1+\gamma}{\gamma}} \quad \rho, \gamma>0
$$

We adopt a utility function that excludes income effects on labor supply; this simplification is in line with, e.g., Saez (2002) and Immervoll et al. (2007). Households can save and borrow freely at the exogenous interest rate $r$, determined by the international capital market in order to smoothen their consumption over their lifetime. Labor supply of the young in period $t$ follows from maximizing (6) subject to the budget constraints (4) and (5) which yields

$$
l_{t}=\left(\left(1-\tau^{w}\right) w_{t}\right)^{\gamma}
$$

$d l_{t} / d w_{t}>0$ since income effects on labor supply are absent. The elasticity of labor supply with respect to the net-of-tax wage rate is equal to $\gamma$.

Land price dynamics are captured by (3). Rearranging terms, all "price-dividend" ratios consistent with arbitrage behavior must satisfy the arbitrage condition (3). For any time profile of land prices $V_{t+i}, i=0, . ., \infty$, we have $R_{t}=R_{t+i}=$ const. in a steady state. The arbitrage equation (3) states that if $V_{t}$ changes and $R_{t}=R_{t+i}=$ const., then $V_{t+1}$ will change by the same amount as $V_{t}$, multiplied by $1+r$. Thus, (3) defines $V_{t+1}$ as a function of $V_{t}$ with slope $d V_{t+1} / d V_{t}=1+r>1$. The function (thick line) is illustrated in Figure 2. A steady state $V_{t}=V_{t+1}=V^{*}$ exists. Furthermore, the steady state is unique and exhibits 


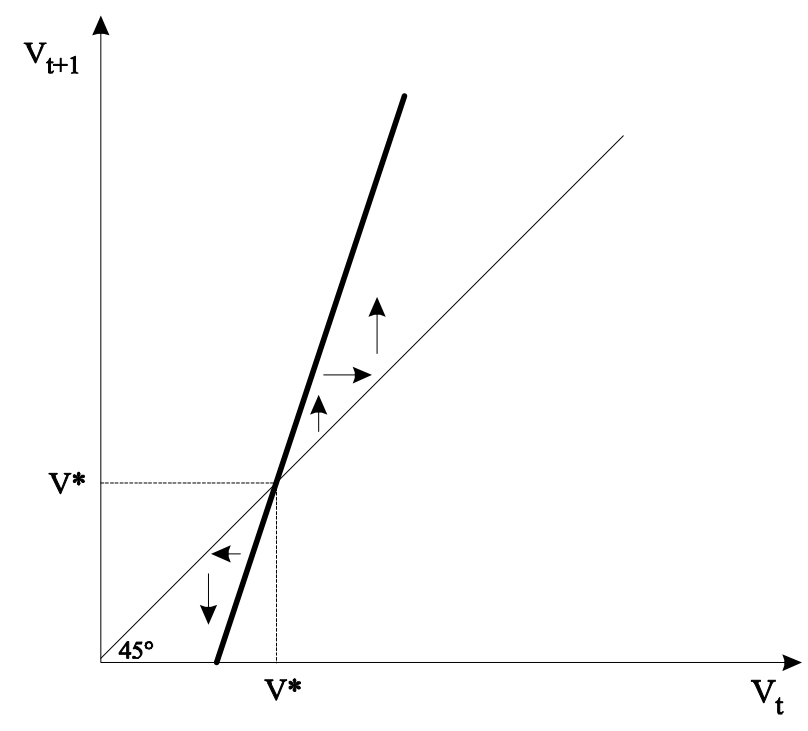

Figure 2: Steady state.

point stability. That is, for any value $V_{t} \neq V^{*}$ the only adjustment in the land price which is consistent with perfect foresight is an immediate jump to $V^{*}$.

To relate the land price to the future net-of-tax land rents, we recursively substitute for the land price $V_{t+i}, i=1, . ., \infty$, in (3):

$$
V_{t}=\sum_{i=1}^{\infty} \frac{\left(1-\tau^{R}\right) R_{t+i}}{(1+r)^{i}}
$$

Considering $R_{t+i}$ to be constant from period $t+1$ onwards:

$$
V_{t}=\frac{\left(1-\tau^{R}\right) R_{t+1}}{r}
$$

Any change in land value following a tax reform in period $t$ is captured by a jump in net-of-tax land rents in the subsequent period. Finally, we note that the net foreign assets 
of the economy in period $t, F_{t}$, satisfy the transversality condition $\lim _{T \rightarrow \infty}\left(\frac{1}{1+r}\right)^{T} F_{t+T+1}=0$ as each generation's budget constraint is satisfied over its lifetime and $r>0$.

\section{Rent Tax Reform}

We consider a rise in rent taxes at the beginning of period $t$; before the young generation supplies labor and the current elderly sell their land to the young generation. The proceeds are used to reduce the wage tax. The current young cohort and the newly born generations benefit from the tax reform. They are subject to a lower wage tax and trade land at the new steady state price. The current old cohort experiences a change in the value of land holdings. To verify whether it is a gain or loss, we first define labor demand, capital demand and the wage rate as a function of the wage tax. The first-order condition for capital demand defines $L_{t}\left(K_{t}\right)$ and following $(2) R_{t}\left(K_{t}\right)$. Via the first-order condition for labor demand, we get $w_{t}\left(K_{t}\right)$. Inserting $L_{t}\left(K_{t}\right)$ and $w_{t}\left(K_{t}\right)$ into the labor market clearing condition yields $L_{t}\left(K_{t}\right)=l_{t}\left(\left(1-\tau^{w}\right) w_{t}\left(K_{t}\right)\right)$ which defines $K_{t}\left(\tau^{w}\right)$. The slope of the various functions is ${ }^{4}$

$$
\frac{d L_{t}}{d K_{t}}=\frac{-F_{K K}}{F_{K L}}, \frac{d R_{t}}{d K_{t}}=\frac{L_{t} \Delta}{F_{K L}}, \frac{d w_{t}}{d K_{t}}=\frac{-\Delta}{F_{K L}} \quad \text { and } \quad \frac{d K_{t}}{d \tau^{w}}=\frac{w_{t}\left(K_{t}\right) l_{t}^{\prime}}{l_{t}^{\prime}\left(1-\tau^{w}\right) d w_{t} / d K_{t}-d L_{t} / d K_{t}},
$$

where $\Delta:=F_{K K} F_{L L}-F_{K L}^{2}>0$. Capital employment depends negatively on the level of wage taxation, i.e. $d K_{t} / d \tau^{w}<0$. A higher wage tax discourages labor supply. Since labor and capital are complements in production, this lowers the marginal productivity of capital and thus leads to an outflow of capital. Straightforwardly, the effect of the wage tax on labor supply, $d L_{t} / d K_{t} \cdot d K_{t} / d \tau^{w}$, and on the gross wage rate, $d w_{t} / d K_{t} \cdot d K_{t} / d \tau^{w}$, is negative. Capital employment is not influenced by the rent tax since income changes in response to a

\footnotetext{
${ }^{4} l_{t}^{\prime}$ denotes the derivative of labor supply with respect to the net-of-tax wage rate $\left(1-\tau^{w}\right) w_{t}$.
} 
hike in the rent tax do not affect labor supply.

The public sector budget constraint is $T_{t}=\tau^{w} w_{t} L_{t}+\tau^{R} R_{t}$. Keeping tax revenues constant, tax rates are related $\mathrm{as}^{5}$

$$
\left.\frac{d \tau^{w}}{d \tau^{R}}\right|_{d T_{t}=0}=-\frac{\partial T_{t} / \partial \tau^{R}}{\partial T_{t} / \partial \tau^{w}}
$$

with

$$
\frac{\partial T_{t}}{\partial \tau^{R}}=R_{t}>0 \quad \text { and } \quad \frac{\partial T_{t}}{\partial \tau^{w}}=w_{t} L_{t}+\tau^{w} L_{t} \frac{d w_{t}}{d \tau^{w}}+\tau^{w} w_{t} \frac{d L_{t}}{d \tau^{w}}+\tau^{R} \frac{d R_{t}}{d \tau^{w}}
$$

We consider an economy which is on the up-ward sloping part of the tax revenue hill, $\partial T_{t} / \partial \tau^{w}>0$. Otherwise, a trade-off between rent and wage taxes in terms of tax revenues would not exist. A reduction in the wage tax rate would allow for a cut in the rent tax so as to keep tax revenues constant. An intergenerational Pareto-improvement would trivially follow. We denote the wage tax rate at which $\partial T_{t} / \partial \tau^{w}=0$ by $\bar{\tau}^{w}$.

Using (7), (9) and (10) and invoking stationarity of land rents $\left(R_{t+1}=R_{t}\right)$ we can compute the change in the net-of-tax rent payment and the land price in response to a budget-balancing increase in the rent tax in period $t$ :

$$
\left.\frac{d\left(\left(1-\tau^{R}\right) R_{t}+V_{t}\right)}{d \tau^{R}}\right|_{d T_{t}=0}=-\frac{(1+r) R_{t}}{r}\left(1+\frac{\left(1-\tau^{R}\right) d R_{t} / d \tau^{w}}{\partial T_{t} / \partial \tau^{w}}\right) .
$$

The transition generation benefits from the tax reform if and only if (11) is positive. Resorting to a Cobb-Douglas production function with $\alpha$ and $\beta(\alpha, \beta>0, \alpha+\beta<1)$ denoting the share of output accruing to labor and capital, we find:

Proposition. Consider an economy in which $\partial T_{t} / \partial \tau^{w}>0$. There always exists an

\footnotetext{
${ }^{5}$ Concretely, the derivative is taken w.r.t. the tax rates in period $t$ assuming that the tax rates stay at the new levels in all subsequent periods. Since labor supply jumps to its new steady state level in period $t$ (and so do rents), a budget-balancing reform of the tax mix in period $t$ also balances the public budget in all subsequent periods.
} 
interval of wage tax rates $\left(\underline{\tau}^{w}, \bar{\tau}^{w}\right), \underline{\tau}^{w}<\bar{\tau}^{w}$ and $\underline{\tau}^{w}, \bar{\tau}^{w} \in(0,1)$, for which a change of the tax mix from wage to rent taxation improves welfare of the transition generation .

The proof is relegated to the appendix. A rent tax lowers the land value and rental income, ceteris paribus. The budget-balancing reduction in labor taxes, however, increases labor supply. This, in turn, increases land productivity in the current and future periods. This capitalizes in the land price and may compensate for the negative effect of higher rent taxation, together with the current increase in land rents. In fact, a pre-existing labor tax $\tau^{w}>\underline{\tau}^{w}$ generates a sufficiently large distortion in the economy (being convex in the tax rate) so as to render the net effect on land value and rental income positive. The tax reform thereby raises welfare of the transition generation and of steady state generations. The upper bound $\bar{\tau}^{w}$ ensures that $\partial T_{t} / \partial \tau^{w}>0$. Straightforwardly, for a level of wage taxes above $\bar{\tau}^{w}$ (and thus $\partial T_{t} / \partial \tau^{w}<0$ ) it is feasible to lower both the wage and rent tax while leaving tax revenues constant. As a result, current and future generations benefit from the reform. To illustrate the scope for intergenerationally welfare-enhancing policies, consider $\left(\alpha, \beta, \gamma, \tau^{R}\right)$ $=(0.6,0.3,0.5,0.1)$. When evaluated subject to the condition $\partial T_{t} / \partial \tau^{w}>0$ the range of wage tax rates which sustain a Pareto-improvement is $\left(\underline{\tau}^{w}, \bar{\tau}^{w}\right)=(0.67,0.71)$. The interval extends to unity in the absence of the condition. Even though the minimum required tax rate is high, it is of an empirically relevant magnitude, see Immervoll et al. (2007) who compute the marginal tax rate on working for different income deciles and countries. ${ }^{6}$

\footnotetext{
${ }^{6}$ Therein, the computed tax rate on working hours include income taxes, social security contributions and the value-added tax.
} 


\section{Concluding Discussion}

Governments can rely on various tax bases to finance their expenditures. In the presence of a fixed factor of production, taxing land rents would be the most efficient way of financing public expenditures from the perspective of steady-state generations. However, were a rent tax to be established, its future tax revenues are capitalized in the current asset prices. This creates a conflict of interest between the current owners of land, and future generations.

In this paper, we show that rent taxation, when combined with a budget-balancing reduction in wage taxes, may also benefit transition generations. The key mechanism here is the endogeneity of labor supply. A cut in wage taxes increases current and future labor supply, and this increases the income accruing to land, when land and labor are complements in production. Provided that the initial wage taxes are sufficiently high, this increase in gross rents may outweigh the effects of a moderate hike in the tax on land rents.

Our analysis relies on a simple analytical model, allowing for explicit solutions. One restrictive assumption we make is that the labor supply in the second period of life is zero. Relaxing this assumption would strengthen the case for the reform we analyze. If households also supply labor in the second period of life (possibly partially as they retire in the course of the second period), aggregate labor supply goes up. A reform of the tax mix towards a higher rent taxation and a lower wage taxation induces larger adjustments in aggregate labor supply. Thus, rent payments and the asset prices increase more strongly. Furthermore, the transition generation enjoys a lower wage tax on its second period labor earnings. Both effects widen the prospects of a Pareto-improving tax reform. A further assumption is the simultaneous announcement and implementation of the reform, i.e. the reform is not anticipated. The aligned timing is without loss of generality. If the reform is announced prior to its implementation, the adjustment in the price of land and return on land takes place earlier in time. If the adjustment is positive, the windfall gain is reaped by some generation 
preceding "our" transition generation. Since labor supply is independent of income, this has no effect on labor supply of the preceding generations. The result we derive stays intact.

It is also instructive to discuss the robustness of our results to the existence of alternative distortionary taxes. For instance, a change from residence-based capital taxes (instead of a wage tax) to rent taxes does not yield a Pareto-improvement. A higher return to savings leaves in our model labor supply unaffected. Also, in a small open economy the capital stock stays the same. Hence, the higher rent tax unambiguously lowers the wealth of the transition generation. Differently, a shift from a source-based capital tax to a rent tax suggestively yields similar effects as we have identified in the paper. A lower capital tax yields an inflow of capital and, since capital and labor are complements in production, it also increases labor supply. Both effects capitalize in the price of land and counteract the effect of a higher rent tax on asset wealth of the transition generation. ${ }^{7}$

Finally, incorporating income effects on labor supply may undermine the commonality of interest between transitional generations and steady state generations. When leisure is normal in consumption, a lower wage tax yields an income effect on labor supply which runs against the substitution effect. On net, labor supply may still increase, but at a lower magnitude. As such, the capitalization mechanism is less effective in transferring part of the future welfare gains to the transition generation.

\footnotetext{
${ }^{7}$ In fact, the capitalization effect will be even stronger relative to the effect we obtain when wage taxes are in place. The rationale is that capital is in perfectly elastic supply, while labor is in imperfectly elastic supply.
} 


\section{A Appendix: Proof of the Proposition}

For notational simplicity, we omit the time subscript throughout. Inserting (10) into (11) and invoking stationarity

$$
\begin{aligned}
\left.\frac{d\left(\left(1-\tau^{R}\right) R+V\right)}{d \tau^{R}}\right|_{d T=0} & =-\frac{(1+r) R}{r}\left(1+\frac{\left(1-\tau^{R}\right) \frac{d R}{d \tau^{w}}}{w L+\tau^{w} L \frac{d w}{d \tau^{w}}+\tau^{w} w \frac{d L}{d \tau^{w}}+\tau^{R} \frac{d R}{d \tau^{w}}}\right) \\
& =-\frac{(1+r) R}{r}\left(\frac{w L+\tau^{w} L \frac{d w}{d \tau^{w}}+\tau^{w} w \frac{d L}{d \tau^{w}}+\tau^{R} \frac{d R}{d \tau^{w}}+\left(1-\tau^{R}\right) \frac{d R}{d \tau^{w}}}{w L+\tau^{w} L \frac{d w}{d \tau^{w}}+\tau^{w} w \frac{d L}{d \tau^{w}}+\tau^{R} \frac{d R}{d \tau^{w}}}\right) \\
& =-\frac{(1+r) R}{r}\left(\frac{w L+\tau^{w} L \frac{d w}{d \tau^{w}}+\tau^{w} w \frac{d L}{d \tau^{w}}+\frac{d R}{d \tau^{w}}}{w L+\tau^{w} L \frac{d w}{d \tau^{w}}+\tau^{w} w \frac{d L}{d \tau^{w}}+\tau^{R} \frac{d R}{d \tau^{w}}}\right) .
\end{aligned}
$$

Assuming $\partial T / \partial \tau^{w}=w L+\tau^{w} L \frac{d w}{d \tau^{w}}+\tau^{w} w \frac{d L}{d \tau^{w}}+\tau^{R} \frac{d R}{d \tau^{w}}>0$, a necessary and sufficient condition for (12) to be positive is

$$
w L+\tau^{w} L \frac{d w}{d \tau^{w}}+\tau^{w} w \frac{d L}{d \tau^{w}}+\frac{d R}{d \tau^{w}}<0
$$

Using the chain rule the condition reads

$$
w L+\left(\tau^{w} L \frac{d w}{d K}+\tau^{w} w \frac{d L}{d K}+\frac{d R}{d K}\right) \frac{d K}{d \tau^{w}}<0
$$

Evaluating the responses $\frac{d i}{d K}, i=w, L, K$ (see (8)) for the Cobb-Douglas production function $Y=L^{\alpha} K^{\beta}$

$$
\text { Eq. }(13)=\alpha L^{\alpha} K^{\beta}+\left(\tau^{w} w \frac{1-\beta}{\alpha} \frac{L}{K}+\left(1-\tau^{w}\right)(1-\alpha-\beta) L^{\alpha} K^{\beta-1}\right) \frac{d K}{d \tau^{w}}
$$

Inserting $w=\alpha L^{\alpha-1} K^{\beta}$ and collecting terms 


$$
\text { Eq. }(14)=\alpha L^{\alpha} K^{\beta}+\left(\tau^{w}(1-\beta)+\left(1-\tau^{w}\right)(1-\alpha-\beta)\right) L^{\alpha} K^{\beta-1} \frac{d K}{d \tau^{w}} \text {. }
$$

Using the first-order condition for capital demand, $r=\beta L^{\alpha} K^{\beta-1}$, to substitute for $K$, and rearranging yields

$$
\text { Eq. }(15)=\alpha\left(\frac{\beta}{r}\right)^{\frac{\beta}{1-\beta}} L^{\frac{\alpha}{1-\beta}}+\left(1-\alpha-\beta+\tau^{w} \alpha\right)\left(\frac{\beta}{r}\right)^{-1} \frac{d K}{d \tau^{w}} \text {. }
$$

We decompose $\frac{d K}{d \tau^{w}}$ into $\frac{d K}{d L} \frac{d L}{d \tau^{w}}$. By the first-order condition $r=\beta L^{\alpha} K^{\beta-1}$ we have

$$
\frac{d K}{d L}=\frac{\alpha}{1-\beta}\left(\frac{\beta}{r}\right)^{\frac{1}{1-\beta}} L^{\frac{\alpha}{1-\beta}-1}
$$

Furthermore, labor supply is $l=\left(\left(1-\tau^{w}\right) w_{t}\right)^{\gamma}$. Substituting $w$ by the first-order condition $w=\alpha L^{\alpha-1} K^{\beta}$ and, subsequently, $K$ by the (inverted) first-order condition $r=\beta L^{\alpha} K^{\beta-1}$,

$$
l=\left(\left(1-\tau^{w}\right) \alpha\left(\frac{\beta}{r}\right)^{\frac{\beta}{1-\beta}} L^{\frac{\alpha}{1-\beta}-1}\right)^{\gamma} .
$$

Setting $l=L$ and solving for $L$ yields

$$
L=\left(\left(1-\tau^{w}\right) \alpha\left(\frac{\beta}{r}\right)^{\frac{\beta}{1-\beta}}\right)^{\omega}, \quad \omega:=\frac{\gamma(1-\beta)}{1-\beta+\gamma(1-\alpha-\beta)} .
$$

Taking the derivative

$$
\begin{aligned}
\frac{d L}{d \tau^{w}} & =-\omega\left(\left(1-\tau^{w}\right) \alpha\left(\frac{\beta}{r}\right)^{\frac{\beta}{1-\beta}}\right)^{\omega-1} \alpha\left(\frac{\beta}{r}\right)^{\frac{\beta}{1-\beta}} \\
& =-\omega \frac{1}{1-\tau^{w}} L .
\end{aligned}
$$


Inserting (17) and (18) into (16) we get

Eq. (16) $=\alpha\left(\frac{\beta}{r}\right)^{\frac{\beta}{1-\beta}} L^{\frac{\alpha}{1-\beta}}-\left(1-\alpha-\beta+\tau^{w} \alpha\right)\left(\frac{\beta}{r}\right)^{-1} \frac{\alpha}{1-\beta}\left(\frac{\beta}{r}\right)^{\frac{1}{1-\beta}} L^{\frac{\alpha}{1-\beta}-1} \omega \frac{1}{1-\tau^{w}} L$

$$
\begin{aligned}
& =\alpha\left(\frac{\beta}{r}\right)^{\frac{\beta}{1-\beta}} L^{\frac{\alpha}{1-\beta}}-\left(1-\alpha-\beta+\tau^{w} \alpha\right) \frac{\alpha}{1-\beta}\left(\frac{\beta}{r}\right)^{\frac{\beta}{1-\beta}} L^{\frac{\alpha}{1-\beta}} \omega \frac{1}{1-\tau^{w}} \\
& =\alpha\left(\frac{\beta}{r}\right)^{\frac{\beta}{1-\beta}} L^{\frac{\alpha}{1-\beta}}\left(1-\left(1-\alpha-\beta+\tau^{w} \alpha\right) \frac{1}{1-\beta} \omega \frac{1}{1-\tau^{w}}\right) .
\end{aligned}
$$

Recall, provided $\partial T / \partial \tau^{w}>0$ the sum of rental income and land value of the transitional generation increases, $d\left(\left(1-\tau^{R}\right) R_{t}+V_{t}\right) /\left.d \tau^{R}\right|_{d T_{t}=0}>0$, if and only if

$$
1-\left(1-\alpha-\beta+\tau^{w} \alpha\right) \frac{1}{1-\beta} \omega \frac{1}{1-\tau^{w}}<0
$$

Equivalently stated,

$$
\tau^{w}>\underline{\tau}^{w}:=\frac{1-\beta-(1-\alpha-\beta) \omega}{1-\beta+\omega \alpha}
$$

We next derive the condition under which

$$
\frac{\partial T}{\partial \tau^{w}}=w L+\tau^{w} L \frac{d w}{d \tau^{w}}+\tau^{w} w \frac{d L}{d \tau^{w}}+\tau^{R} \frac{d R}{d \tau^{w}}>0
$$

holds. As can be inferred from (12) the expression is almost congruent to the term $w L+\tau^{w} L \frac{d w}{d \tau^{w}}+\tau^{w} w \frac{d L}{d \tau^{w}}+\frac{d R}{d \tau^{w}}$ which we stepwise rearranged to arrive at (20). Reiterating the same steps, the condition for $\partial T_{t} / \partial \tau^{w}>0$ reads

$$
\tau^{w}<\bar{\tau}^{w}:=\frac{1-\beta-\tau^{R}(1-\alpha-\beta) \omega}{1-\beta+\omega \alpha}
$$


Straightforwardly, $\underline{\tau}^{w}<\bar{\tau}^{w}$ since $\tau^{R}<1$. A change in the tax mix from wage to rent taxation increases land value if and only if $\tau^{w} \in\left(\underline{\tau}^{w}, \bar{\tau}^{w}\right)$.

We next prove that $\underline{\tau}^{w}, \bar{\tau}^{w} \in(0,1)$. We first compute the derivative

$$
\begin{aligned}
\frac{d \omega}{d \gamma} & =\frac{(1-\beta)(1-\beta+\gamma(1-\alpha-\beta)-\gamma(1-\alpha-\beta))}{(1-\beta+\gamma(1-\alpha-\beta))^{2}} \\
& =\frac{(1-\beta)^{2}}{(1-\beta+\gamma(1-\alpha-\beta))^{2}}>0 .
\end{aligned}
$$

Turning to the slope of $\underline{\tau}^{w}$ with respect to $\omega$

$$
\begin{aligned}
\frac{d \underline{\tau}^{w}}{d \omega} & =\frac{-(1-\alpha-\beta)(1-\beta+\omega \alpha)-(1-\beta-(1-\alpha-\beta) \omega) \alpha}{(1-(1-\omega) \alpha)^{2}} \\
& =\frac{-(1-\beta)^{2}}{(1-(1-\omega) \alpha)^{2}}<0 .
\end{aligned}
$$

Similarly,

$$
\begin{aligned}
\frac{d \bar{\tau}^{w}}{d \omega} & =\frac{-\tau^{R}(1-\alpha-\beta)(1-\beta+\omega \alpha)-\left(1-\beta-\tau^{R}(1-\alpha-\beta) \omega\right) \alpha}{(1-(1-\omega) \alpha)^{2}} \\
& =\frac{-(1-\beta)\left(\alpha+\tau^{R}(1-\alpha-\beta)\right)}{(1-(1-\omega) \alpha)^{2}}<0 .
\end{aligned}
$$

Therefore, combining results

$$
\frac{d i}{d \omega} \frac{d \omega}{d \gamma}<0, \quad i=\underline{\tau}^{w}, \bar{\tau}^{w}
$$

To determine the maximal and minimal value of $\underline{\tau}^{w}$ and $\bar{\tau}^{w}$, we first observe that 


$$
\lim _{\gamma \rightarrow 0} \omega=0
$$

and, applying L'Hôpital's rule, we find

$$
\lim _{\gamma \rightarrow \infty} \omega=\frac{1-\beta}{1-\alpha-\beta}
$$

Given by (21) and (22)

$$
\lim _{\gamma \rightarrow 0} \underline{\tau}^{w}=1 \quad \text { and } \quad \lim _{\gamma \rightarrow \infty} \underline{\tau}^{w}=0
$$

and

$$
\lim _{\gamma \rightarrow 0} \bar{\tau}^{w}=1 \quad \text { and } \quad \lim _{\gamma \rightarrow \infty} \bar{\tau}^{w}=\frac{\left(1-\tau^{R}\right)(1-\alpha-\beta)}{1-\beta} \in(0,1)
$$

Thus, $\underline{\tau}^{w}, \bar{\tau}^{w} \in(0,1)$ which completes the proof.

\section{References}

[1] Calvo, G., Kotlikoff, L., Rodriguez, C., 1979. The incidence of a tax on pure rent: a new (?) reason to an old answer. Journal of Political Economy 87, 869-874.

[2] Chamley, C., Wright, B., 1987. Fiscal incidence in an overlapping generations model with a fixed asset. Journal of Public Economics 32, 3-24.

[3] Eaton, J., Foreign-owned land. American Economic Review 78, 76-88.

[4] Feldstein, M., 1977. The surprising incidence of a tax on pure rent: a new answer to an old question. Journal of Political Economy 92, 329-333. 
[5] Gordon, R.H., Bovenberg, A.L., (1996). Why is capital so immobile internationally? Possible explanations and implications for capital income taxation. American Economic Review 86, 1057-1075.

[6] Ihori, T., 1990. Economic effects of land taxes in an inflationary economy. Journal of Public Economics 42, 195-211.

[7] Immervoll, H., Kleven, H., Kreiner, C.T., Saez, E., 2007, Welfare reforms in European countries: a microsimulation analysis. Economic Journal 117, 1-44.

[8] Koethenbuerger, M., Poutvaara, P., 2006. Social security reform and investment in education: Is there scope for a Pareto-improvement?. Economica 72, 299-319.

[9] Petrucci, A., 2006. The incidence of a tax on pure rent in a small open economy. Journal of Public Economics 90, 921-933.

[10] Poutvaara, P., 2003. Gerontocracy revisited: unilateral transfer to the young may benefit the middle-aged. Journal of Public Economics 88, 161-174.

[11] Rangel, A., 2003. Forward and backward intergenerational goods: Why is social security good for the environment?. American Economic Review 93 , 813-834.

[12] Rangel, A., 2005. How to protect future generations using tax base restrictions. American Economic Review 95, 314-346.

[13] Saez, E., 2002. Optimal income transfer programs: intensive versus extensive labor supply responses. Quarterly Journal of Economics 117, 1039-1073. 


\section{CESifo Working Paper Series}

for full list see www.cesifo-group.org/wp

(address: Poschingerstr. 5, 81679 Munich, Germany, office@cesifo.de)

2096 Louis N. Christofides and Amy Chen Peng, Real Wage Chronologies, September 2007

2097 Martin Kolmar and Andreas Wagener, Tax Competition with Formula Apportionment: The Interaction between Tax Base and Sharing Mechanism, September 2007

2098 Daniela Treutlein, What actually Happens to EU Directives in the Member States? - A Cross-Country Cross-Sector View on National Transposition Instruments, September 2007

2099 Emmanuel C. Mamatzakis, An Analysis of the Impact of Public Infrastructure on Productivity Performance of Mexican Industry, September 2007

2100 Gunther Schnabl and Andreas Hoffmann, Monetary Policy, Vagabonding Liquidity and Bursting Bubbles in New and Emerging Markets - An Overinvestment View, September 2007

2101 Panu Poutvaara, The Expansion of Higher Education and Time-Consistent Taxation, September 2007

2102 Marko Koethenbuerger and Ben Lockwood, Does Tax Competition Really Promote Growth?, September 2007

2103 M. Hashem Pesaran and Elisa Tosetti, Large Panels with Common Factors and Spatial Correlations, September 2007

2104 Laszlo Goerke and Marco Runkel, Tax Evasion and Competition, September 2007

2105 Scott Alan Carson, Slave Prices, Geography and Insolation in $19^{\text {th }}$ Century AfricanAmerican Stature, September 2007

2106 Wolfram F. Richter, Efficient Tax Policy Ranks Education Higher than Saving, October 2007

2107 Jarko Fidrmuc and Roman Horváth, Volatility of Exchange Rates in Selected New EU Members: Evidence from Daily Data, October 2007

2108 Torben M. Andersen and Michael Svarer, Flexicurity - Labour Market Performance in Denmark, October 2007

2109 Jonathan P. Thomas and Tim Worrall, Limited Commitment Models of the Labor Market, October 2007

2110 Carlos Pestana Barros, Guglielmo Maria Caporale and Luis A. Gil-Alana, Identification of Segments of European Banks with a Latent Class Frontier Model, October 2007 
2111 Felicitas Nowak-Lehmann D., Sebastian Vollmer and Immaculada Martínez-Zarzoso, Competitiveness - A Comparison of China and Mexico, October 2007

2112 Mark Mink, Jan P.A.M. Jacobs and Jakob de Haan, Measuring Synchronicity and Comovement of Business Cycles with an Application to the Euro Area, October 2007

2113 Ossip Hühnerbein and Tobias Seidel, Intra-regional Tax Competition and Economic Geography, October 2007

2114 Christian Keuschnigg, Exports, Foreign Direct Investment and the Costs of Corporate Taxation, October 2007

2115 Werner Bönte, Oliver Falck and Stephan Heblich, Demography and Innovative Entrepreneurship, October 2007

2116 Katrin Assenmacher-Wesche and M. Hashem Pesaran, Assessing Forecast Uncertainties in a VECX Model for Switzerland: An Exercise in Forecast Combination across Models and Observation Windows, October 2007

2117 Ben Lockwood, Voting, Lobbying, and the Decentralization Theorem, October 2007

2118 Andrea Ichino, Guido Schwerdt, Rudolf Winter-Ebmer and Josef Zweimüller, Too Old to Work, too Young to Retire?, October 2007

2119 Wolfgang Eggert, Tim Krieger and Volker Meier, Education, Unemployment and Migration, October 2007

2120 Stefan Napel and Mika Widgrén, The European Commission - Appointment, Preferences, and Institutional Relations, October 2007

2121 Bertil Holmlund and Martin Söderström, Estimating Income Responses to Tax Changes: A Dynamic Panel Data Approach, October 2007

2122 Doina Maria Radulescu, From Separate Accounting to Formula Apportionment: Analysis in a Dynamic Framework, October 2007

2123 Jelle Brouwer, Richard Paap and Jean-Marie Viaene, The Trade and FDI Effects of EMU Enlargement, October 2007

2124 Kurt R. Brekke, Luigi Siciliani and Odd Rune Straume, Competition and Waiting Times in Hospital Markets, October 2007

2125 Alexis Direr, Flexible Life Annuities, October 2007

2126 Johannes Becker and Clemens Fuest, Quality versus Quantity - The Composition Effect of Corporate Taxation on Foreign Direct Investment, October 2007

2127 Balázs Égert, Real Convergence, Price Level Convergence and Inflation Differentials in Europe, October 2007 
2128 Marko Koethenbuerger, Revisiting the "Decentralization Theorem” - On the Role of Externalities, October 2007

2129 Axel Dreher, Silvia Marchesi and James Raymond Vreeland, The Politics of IMF Forecasts, October 2007

2130 Andreas Knabe and Ronnie Schöb, Subsidizing Extra Jobs: Promoting Employment by Taming the Unions, October 2007

2131 Michel Beine and Bertrand Candelon, Liberalization and Stock Market Co-Movement between Emerging Economies, October 2007

2132 Dieter M. Urban, FDI Technology Spillovers and Wages, October 2007

2133 Valentina Bosetti, Carlo Carraro, Emanuele Massetti and Massimo Tavoni, Optimal Energy Investment and R\&D Strategies to Stabilise Greenhouse Gas Atmospheric Concentrations, October 2007

2134 David-Jan Jansen and Jakob de Haan, The Importance of Being Vigilant: Has ECB Communication Influenced Euro Area Inflation Expectations?, October 2007

2135 Oliver Falck, Heavyweights - The Impact of Large Businesses on Productivity Growth, October 2007

2136 Xavier Freixas and Bruno M. Parigi, Banking Regulation and Prompt Corrective Action, November 2007

2137 Jan K. Brueckner, Partial Fiscal Decentralization, November 2007

2138 Silvia Console Battilana, Uncovered Power: External Agenda Setting, Sophisticated Voting, and Transnational Lobbying, November 2007

2139 Alan J. Auerbach, Michael P. Devereux and Helen Simpson, Taxing Corporate Income, November 2007

2140 Lorenzo Cappellari, Paolo Ghinetti and Gilberto Turati, On Time and Money Donations, November 2007

2141 Roel Beetsma and Heikki Oksanen, Pension Systems, Ageing and the Stability and Growth Pact, November 2007

2142 Hikaru Ogawa and David E. Wildasin, Think Locally, Act Locally: Spillovers, Spillbacks, and Efficient Decentralized Policymaking, November 2007

2143 Alessandro Cigno, A Theoretical Analysis of the Effects of Legislation on Marriage, Fertility, Domestic Division of Labour, and the Education of Children, November 2007

2144 Kai A. Konrad, Mobile Tax Base as a Global Common, November 2007 
2145 Ola Kvaløy and Trond E. Olsen, The Rise of Individual Performance Pay, November 2007

2146 Guglielmo Maria Caporale, Yannis Georgellis, Nicholas Tsitsianis and Ya Ping Yin, Income and Happiness across Europe: Do Reference Values Matter?, November 2007

2147 Dan Anderberg, Tax Credits, Income Support and Partnership Decisions, November 2007

2148 Andreas Irmen and Rainer Klump, Factor Substitution, Income Distribution, and Growth in a Generalized Neoclassical Model, November 2007

2149 Lorenz Blume, Jens Müller and Stefan Voigt, The Economic Effects of Direct Democracy - A First Global Assessment, November 2007

2150 Axel Dreher, Pierre-Guillaume Méon and Friedrich Schneider, The Devil is in the Shadow - Do Institutions Affect Income and Productivity or only Official Income and Official Productivity?, November 2007

2151 Valentina Bosetti, Carlo Carraro, Emanuele Massetti and Massimo Tavoni, International Energy R\&D Spillovers and the Economics of Greenhouse Gas Atmospheric Stabilization, November 2007

2152 Balázs Égert and Dubravko Mihaljek, Determinants of House Prices in Central and Eastern Europe, November 2007

2153 Christa Hainz and Hendrik Hakenes, The Politician and his Banker, November 2007

2154 Josef Falkinger, Distribution and Use of Knowledge under the "Laws of the Web", December 2007

2155 Thorvaldur Gylfason and Eduard Hochreiter, Growing Apart? A Tale of Two Republics: Estonia and Georgia, December 2007

2156 Morris A. Davis and François Ortalo-Magné, Household Expenditures, Wages, Rents, December 2007

2157 Andreas Haufler and Christian Schulte, Merger Policy and Tax Competition, December 2007

2158 Marko Köthenbürger and Panu Poutvaara, Rent Taxation and its Intertemporal Welfare Effects in a Small Open Economy, December 2007 